\title{
The Role of Youth in Preventing Violent Extremism in Indonesia. A Study of Duta Damai
}

\author{
M Z Achsin \\ Universitas Brawijaya, Malang \\ muhaimin.zul@ub.ac.id,
}

\begin{abstract}
This study aimed to describe the role of youth in preventing and countering violent extremism in Indonesia particularly Duta Damai. Duta Damai/peace ambassador is youth community that was made by the National Agency for Combating Terrorism (BNPT/ Badan Nasional Penanggulangan Terrorisme). Qualitative approach with the descriptive research purpose became main approach in this research. Moreover, this study poses a question how does youth contribute to the preventing violent extremism (PVE) and countering violent extremism (CVE) in Indonesia through community of Duta Damai? Both of primary data and secondary data were collected by the researchers through interview and online data excavating. Five categories of youth work against violent radicalization which was provided by the European Commission is using as the categories in this study. The result shown that Duta Damai has implemented five categories mentioned before. However, Duta Damai is still lacking in some points.
\end{abstract}

Keywords: Duta Damai, Countering Violent Extremism, Indonesia, Preventing Violent Extremism, Youth

\section{INTRODUCTION}

In case of Surabaya bombings on 13 May 2018, two sons of family of six who named Yusuf (aged 18) and Firman (aged 16) followed their parent's order to attack one chruch by exploding themselves. This was shocking beacuse at their age they had certain freedom to choose some alternatives way of life. Edelman and Kudzma [1] has explained that "adolescent tends to seek their own identity. Adolescents may challenge family values and standard eventhough parent maintains some authorities". However, Yusuf (a senior high school student) and Firman (a junior high school student) who are in puberty stage can not challenge their parents' order and can not alter the decision to end their potential lifes through suicide mission. Therefore, the youth involvement in violent extremism action became crucial concern in society of Indonesia today.

Schools as the institution that effects students also shown vulnerable supporting system to the students. According to research of PPIM UIN Jakarta and UNDP Indonesia through the Convey project depicted that $63,07 \%$ teachers had intolerance opinions on the different religions implicitly, meanwhile explicitly 56,90\% teachers had intolerance opinions on the different religions. That survey conducted from 6 August to 6 September 2019 with the 2.237 sampling (male: 898 (40,21\%), female 1335 (59,79\%)) in 767 cities/regencies in Indonesia using proportional probability technique [2]. It means that the spreading of intolerance that 
germ of extremism and radicalism based on religion might be disseminating in school through educational processes.

Dja'far, a researcher from Wahid institute, stated that there are several factors why intolerance in school in Indonesia became stronger than before. Firstly, stakeholders in educational system in shcool are still lacking vision of tolerance. Some of them neglect the intolerance and discrimination embrio on their students. Morover, it can be influencing from the narrow and bias inerpretation of national law on educational system that mentioned national education system rooted on the religion values, national cultures and responsive of changes. The narrow interpretation on religion values, as if it based on only particularly majority religion which is Islam, not the universal values of all religion itself. Secondly, the difficulties of stakeholders and teachers in school to distinguish between private field of belief and the basic value that they hold as the government apparatus that must be advancing the tolerance, humanity and plurality principles. Thirdly, the absence of moderate mass reiligous organizations such as Nahdlatul Ulama and Muhammadiyah embraced the students to open their mind in the moderate vision particularly in state/public schools [3]. However, mainstreaming the potential of tolerance thought as the preventive of violent extremism in educational institution had been done intensively at this time by both of state programs and civil society organizations' programs.

According to Davydov there are five causes of youth extremism "the first cause attributes to certain essential traits of that age (striving to be actively involved and overcome obstacles). Youth inclines propensity toward taking risks, seeking advanture, and pursuing social heroism. The second cause related to the search for identity, individual's crisis of identity be separated from social crises, ignoring of society's norms and values. The third cause attributed to the authoritarian personality complex, a propensity toward unwavering respect within a group, concern with matters of power and status, stereotypical judgements and assessments, and intolerance toward uncertainty. The fourth cause is rooted in society's dominant culture, the culture of violence in society including in the education environment. The fifth cause is from unfovarable economic and social conditions as well as people's dissatisfaction with their position"[4]. The explanation of Davydov speaks about wide range of social psychological, culture, and economic dimension. However, ideological factor or brain washing (offline and online) and the family factor are still not mentioned yet. Several studies have been done regaridng the role of youth in preventing violent extremism [5]-[13].

Therefore to prevent radicalism and extremism based on religion that targeted youth, BNPT, a leading state apparatus in combating terrorism, created Duta Damai communities. Duta Damai consist of youth that must possess three basic skills namely blogging, visual communication design and information technology. BNPT established Duta Damai/peace ambassadors in 13 provinces consist of 780 youth in total. According to the largest numbers of this community members that made by government, it is interesting to examine the activities of this community. This research poses the question how does youth contribute to the preventing violent extremism (PVE) and countering violent extremism (CVE) in Indonesia through community of Duta Damai/peace ambassadors?

\section{RESEARCH METHOD}

This research was conducted in 2019 by using of qualitative approach with the descriptive purposes. Both primary and secondary data was collected during this research through interview and online data excavating. Analysis data technique using Flick [14] phases namely categorization, reduction, condensation, and interpretation. This research is using five 
categories namely peer education, online campaigns and digital media, co-operation with other stakeholders, providing opportunities, education and training which had been provided by Council of Europe to examine the role of youth in preventing violent extremism [15].

\section{RESULTS AND DISCUSSION}

Peer education in these one of five categories will be using indicator of young educators engage in an educational process as the approach to preventing radicalism and discrimination leading to violence. Morover the activities can be training in schools as well as visits to place that connected with the substantive goals.

Duta damai in North Sumatera made a program namely Duta Damai Goes to School. They tried to engage with the student through peace campaign. Its activites packaged in crative media workshop that stressing on peace contents as well as avoid hoax, hate speech, disintegrity, and radicalism that leading to violent actions. Students of MAN (Madrasah Aliyah Negeri/Islamic Senior High School) 1 Medan as the main participants of that event [16].

It can be drawing from that activities that Duta Damai as the young educators realized the potentials of student being peace campaigners who have creativity both offline and online related to the effort of preventing and countering violent extremism in society particularly young people. Furthermore, it also can be advancing the knowledge of the students in order to broaden youth horizon particulary when it comes to working together with other social groups in societies. However, there also some critical points here namely the sustainability of the program and the reach of audience. That activity did not occur gradually and implement in other areas as many as the brances of Duta Damai in Indonesia. In the other name it did not design in comprehensive and top down that must be running by all of Duta Damai members in Indonesia since this community top-down based.

Online and media digital are the core approach that lies on the Duta Damai all programs. Every single person of peace ambassador or Duta Damai members has to possess three basic skills namely information technology, visual communication - design and blogging. Duta Damai/peace ambassador was recruited in 13 provinces of Indonesia. Each Duta Damai has to make their own online social medias which disseminating through the channels of twitter, Instagram, facebook and youtube. On the Youtube channels, it is under the channel of DamailahRI, a channel that owned by the BNPT's center media. Every single article or social media posting, it contains a peace content. By adding some nationalism and tolerance ideas on each posting, Duta Damai tries to spread more soft approach to campaigning social harmony and prevent violent extremism particularly targeted youth as media literacy purposes. Moreover, the predominance of Duta Damai is a huge number of its members, there are 780 youth recruited as the peace ambassadors/Duta Damai's members. It is the biggest the "manpower" of BNPT arms.

However, to prevent violent extremism propaganda on social media, Duta Damai did not involve in the debate on the social medias that spreading extremism narration. Counter narration runs on their own track. Furthermore, it is difficult to asses whether the Duta Damai's social medias are hiting the right audiences or not. Because it seems like the social medias passively counter narration and reach wider vulnerable audiences.

Co-operation with other stakeholders mainly done by the Duta Damai with the FKPT (Forum Koordinasi Pencegahan Terrorisme / Terrorism Prevention Coordinating Forum). FKPT is a forum made by BNPT that consists of community and religion leaders, FKPT also established in 32 provinces of Indonesia. This stakeholder has the same misson with the Duta 
Damai that focusing on the education (social and religion), research, community empowering (youth, men and women), mass media partnership and other social as well as cultural activities. FKPT also helps Duta Damai as the early warning system when the extremist ideology spreading on the ambit of particular areas. Moreover, Duta Damai also cooperates with the local policemen to emphasize nationalism values to the society. The important point is the networking between Duta Damai with the other civil society organizations and communities such as Gusdurian to spread tolerance, pluralism and social harmony. Furthermore, the main organ, BNPT, tries to leverage the best practice of terrorism prevention action to the level of south-east Asian nations through ASEAN. When it applied, it means that the cooperation of Duta Damai would extend to regional level of stakeholders and communities.

Providing opportunities to the youth to see many alternatives of harmony of life, Duta Damai was making an interfaith dialogue to other believers. The dialogue is emphasizing that the difference is the gift from God, an inevitability. However, the economy empowerement regarding providing opportunities as the one indicator of preventing violent extremism from economic dimension still not done yet by the Duta Damai. Duta Damai not yet touched the preventing terrorism from the poverty reduction point of view. It is due to lack of financial support of this organization from external funding. Duta Damai relies on the financial support from BNPT as the main organ.

Speaking about financial/economic as the one of root problems, there was evidence story of Farida in Cox's Bazar Bangladesh when she told story about her neighbor. She wrote[17]:

"I have neighbor named Ahnaf, he is an educated person but didn't get a job. For this reason, he always gets angry with his family members as well as himself. Sometimes he becomes so angry that he can't control himself and breaks things like furniture. A while ago, I began to see these major changes in his character, he seemed frustrated with every matter in society...I saw that he was gradually ill tempered...he became separated from us...he began associating with people who are extremist in every aspect of their lives...he argued that the followers of Islam are mostly victimized in the world."

That story depicted us that the extreme thought appeared as the results or accummulation of many material preconditions mostly economic problem that pushing person into frustrating zone. Eventhough that story happened in Bangladesh, it can not be treated as the local/particular phenomena, it was a global phenomenon. As leader of Nahdlatul Ulama, Said Aqil Siroj, stated that cause factors of terrorism in Indonesia are poverty and inequality [18]. Alan Krueger also shared the same argument, economic dimension as the main driven of person who became a terrorist [19].However, the argument that hold assumption that poverty as the root cause of terrorism in Indonesia would face many opposite arguments that emphasizing the ideology framed in religious terms as the root terrorism factor in Indonesia. Sidney Jones, a terrorist expert in Indonesia - director of IPAC, stated that there is no correlation betwen poverty and terrorist recruitment target [20].

Education and training emphasizing by the Duta Damai were the training of the utilization of information technology to create peace and tolerant content, combat hoax and raising awareness of the danger of the online media propaganda. Before members of Duta Damai recruited, they obtained the workshop from several stakeholders. However, Duta Damai's members seldom provide the workshop for public systematically and gradually as the 
comprehensive projects to upgrade capacity of youth and public to deal explicitly with the violent extremist and terrorist topics. Ideally, to prevent violent extremism or radicalization requires a better understanding and willingness to learn, build trust, learn and engage as well as know how to approach young targeted by extremism.

Overall, Duta Damai has been implementing five categories namely peer education, online and media digital, co-operation with stakeholders, providing opportunities, and education and training. The dominant effort lies on the online and media digital, nonetheless infrequent effort in providing opportunities regarding economic empowerement. That results based on firstly the initial Duta Damai's establishment was to help BNPT tackling or preventing online media propaganda that targeted youth in the cyberspace, and secondly the lacking of financial support of this organization as well as the idea of economic as root cause terrorism is not mainstreaming on the idea of Duta Damai's members.

The identification of challenges of this community are firstly, this community made by state therefore images from the society seeing the community related to state apparatus are just ordinary to certain extent is poor. That public perception was due to the negative stigma that every single organ that made by state only for the budgeting purposes or economic benefit. Therefore, it becomes a stumbling block of the pro bono spirit of Duta Damai's members who are truly and voluntarily work for preventing violent extremism. Nevertheless, that obstacles could be overcame by the making of networking with the other independent community which has the same vision and spirit.

In Indonesia context regarding the prevent action of violent extremism, it needs basic social trust among the grassroots community to create supportive environment for both of civil social organizations and society. The problems are the radical groups spreading the online propaganda in the nuance of puritanism that contrary with the moderate moslem groups that championing the idea pluralism and peaceful religion. It supposed to make a debate in order to open the public mind. However, this activity rarely happened.

\section{CONCLUSIONS}

Based on the ideas and practices, it examines the role of youth in preventing violent extremism through the Duta Damai community by implementing five categories namely peer education, online and media digital, co-operation with stakeholders, providing opportunities, and education and training. Each category has been done by the Duta Damai through several programs that run in different areas or provinces. The role of Duta Damai manifested through various efforts fo instance as the instructor, blogger, educator, speaker and so on so forth. As the biggest "manpower" of BNPT to prevent violent extremism in Indonesia, Duta Damai mostly targeted counter extremism narration on social medias. However, they are not trying to get involved in debate with the radical groups, the counter narration runs on their own track. One of categories namely providing opportunities rarely implemented by the Duta Damai particularly on economic empowerement. Furthermore, it shows that the lacking of systematical programs or plans designed by the Duta Damai in Indonesia which able to evaluate the output whether is success or fail objectively, are they hitting the right audiences?

\section{REFERENCES}

[1] E. C. K. Carole Lium Edelman, Health Promotion Throughout the Life Span, Ninth. Missouri: Elsevier, 2018.

[2] Convey, "PELITA YANG MEREDUP : KeberAGAMAan GURU Sekolah / 
Madrasah di," vol. 2, no. 1, 2019.

[3] Alamsyah M. Dja'far, "Intoleransi Kaum Pelajar,” 2015. [Online]. Available: http://www.wahidinstitute.org/wi-id/indeks-opini/280-intoleransi-kaum-pelajar.html. [Accessed: 03-Dec-2019].

[4] D. G. Davydov, "The Causes of Youth Extremism and Ways to Prevent It in the Educational Environment," Russ. Soc. Sci. Rev., vol. 56, no. 5, pp. 51-64, 2015.

[5] R. Broadbent, "Using grass roots community programs as an anti-extremism strategy," Aust. J. Adult Learn., 2013.

[6] B. H. Ellis and S. Abdi, "Building community resilience to violent extremism through genuine partnerships," Am. Psychol., 2017.

[7] M. Costello, J. Hawdon, T. Ratliff, and T. Grantham, "Who views online extremism? Individual attributes leading to exposure," Comput. Human Behav., 2016.

[8] K. Christmann, "Preventing religious radicalisation and violent extremism: A systematic review of the research evidence.," Youth Justice Board, 2012.

[9] A. Van De Weert and Q. A. M. Eijkman, "Behavioral Sciences of Terrorism and Political Aggression Subjectivity in detection of radicalisation and violent extremism : a youth worker's perspective," Behav. Sci. Terror. Polit. Aggress., vol. 0, no. 0, pp. $1-24,2018$.

[10] D. Afrianty, "Journal of Policing, Intelligence and Islamic education and youth extremism in Indonesia," no. December 2014, pp. 37-41, 2012.

[11] A. Özerdem and S. Podder, "Disarming Youth Combatants: Mitigating Youth Radicalization and Violent Extremism," J. Strateg. Secur., 2011.

[12] M. Lombardi, "Countering radicalisation and violent extremism among youth to prevent terrorism," NATO science for peace and security series E, Human and societal dynamics. 2015.

[13] P. Thomas, "Youth, terrorism and education: Britain's Prevent programme," Int. J. Lifelong Educ., 2016.

[14] T. S. Handbook, <Uwe Flick (ed.)-The SAGE Handbook of Qualitative Data AnalysisSAGE Publications (2013).pdf>. .

[15] M. Angel, G. López, and L. Pašić, "Youth work against violent radicalisation: Theory, concepts and primary prevention in practice," 2017.

[16] "Duta Damai Sumut Goes to School." .

[17] GCERF, "A Youth Perspective on Preventing Violent Extremism."

[18] Rofiuddin, "Ketua PBNU: Terorisme Dipicu Faktor Kemiskinan,” 21-Dec-2010.

[19] Alan B. Krueger, What Makes a Terrorist: Economics and the Roots of Terrorism. Princenton University Press, 2018.

[20] CNN, "Sydney Jones Sebut Tidak Ada Kaitan Kemiskinan dan Terorisme," 13-Apr2018. 